University of Nebraska - Lincoln

DigitalCommons@University of Nebraska - Lincoln

Faculty Publications from the Harold W. Manter Laboratory of Parasitology

4-1978

Spirocamallanus cricotus sp. $\mathrm{n}$. and S. halitrophus sp. $\mathrm{n}$. (Nematoda: Camallanidea) from Fishes in the Northern Gulf of Mexico

\author{
Alan C. Fusco \\ University of Illinois \\ Robin M. Overstreet \\ Gulf Coast Research Laboratory, robin.overstreet@usm.edu
}

Follow this and additional works at: https://digitalcommons.unl.edu/parasitologyfacpubs

Part of the Parasitology Commons

Fusco, Alan C. and Overstreet, Robin M., "Spirocamallanus cricotus sp. n. and S. halitrophus sp. n. (Nematoda: Camallanidea) from Fishes in the Northern Gulf of Mexico" (1978). Faculty Publications from the Harold W. Manter Laboratory of Parasitology. 489.

https://digitalcommons.unl.edu/parasitologyfacpubs/489

This Article is brought to you for free and open access by the Parasitology, Harold W. Manter Laboratory of at DigitalCommons@University of Nebraska - Lincoln. It has been accepted for inclusion in Faculty Publications from the Harold W. Manter Laboratory of Parasitology by an authorized administrator of DigitalCommons@University of Nebraska - Lincoln. 


\title{
SPIROCAMALLANUS CRICOTUS SP. N. AND S. HALITROPHUS SP. N. (NEMATODA: CAMALLANIDEA) FROM FISHES IN THE NORTHERN GULF OF MEXICO*
}

\author{
Alan C. Fusco and Robin M. Overstreet \\ Gulf Coast Research Laboratory, Ocean Springs, Mississippi 39564
}

ABSTRACT: Spirocamallanus cricotus sp. n. ( = S. pereirai, in part) and S. halitrophus sp. n. are described from marine fishes of the northern Gulf of Mexico. Spirocamallanus cricotus has a ledge anterior to the basal ring in the buccal capsule, similar spicules with a ratio of $1: 1.4$ to $2.1,3$ pre- and 5 postcloacal papillae, and 8 rectal glands in the female; $S$. halitrophus lacks the ledge and possesses dissimilar spicules with a ratio of $1: 1.3$ to $1.8,3$ pre- and 6 postcloacal papillae, and 4 rectal glands in the female.

Three species of Spirocamallanus Olsen 1952 have been reported from marine and estuarine fishes of the western Atlantic: S. macensis Vicente and Santo 1971 from Brazil, S. pereirai (Annereaux 1946) Olsen 1952 from the northern Gulf of Mexico, and S. spiralis (Baylis 1923) Olsen 1952 from Veracruz, Mexico. However, we question the identification of S. pereirai reported by SogandaresBernal (1955) and Joy $(1971,1974)$ and S. spiralis reported by Winter (1953). We consider S. pereirai to be restricted to the Pacific Ocean and also doubt that $S$. spiralis, originally described from freshwater catfish in Egypt and identified from females by Winter, occurs in the Gulf of Mexico.

The genus Spirocamallanus has not been accepted as distinct from Procamallanus Baylis 1923 by all workers (e.g., Ali, 1960; Yamaguti, 1961). However, we agree with Yeh (1960) and Bashirullah (1973) in retaining the genus on the basis of members having spiraled thickenings in the buccal capsule. Furthermore, members of Procamallanus are restricted to the Indo-Pacific region and Africa with the exception of one atypical South American species, whereas those of Spirocamallanus have a wide distribution in both the New and Old Worlds.

\section{MATERIALS AND METHODS}

Living specimens of the first species described below were fixed in glacial acetic acid and stored in $70 \%$ ethanol with 5 parts of glycerine, whereas those of the second were removed from formalin-

Received for publication 1 July 1977.

* This study was conducted in cooperation with the U.S. Department of Commerce, NOAA, National Marine Fisheries Service, under PL 88309, Project No. 2-262-R. fixed fish that had been transferred to $40 \%$ isopropanol. All nematodes were cleared in glycerine or lactic acid for examination. Measurements are in micrometers unless otherwise stated; figures were drawn with the aid of a drawing tube.

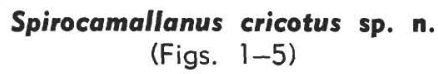

Description (based on specimens from Micropogonias undulatus ): Body with region of greatest width at midlevel or slightly anterior. Lips lacking; cephalic papillae elongated, in 3 concentric rings of 4 oriented $45^{\circ}$ from dorsal-ventral axis; amphids lateral. Mouth dorsoventrally elongated. Cuticle with fine transverse striations and straight longitudinal ridges. Deirids absent. Buccal capsule with 10 to 15 (avg 12.6) spiral bands when counted diagonally; ledge anterior to basal ring distinct. Esophagus with anterior muscular portion moderately club-shaped and posterior glandular portion elongated, ending in paired bilobed valves. Nerve ring at level of anterior $1 / 3$ to $1 / 2$ of muscular esophagus. Excretory pore posterior to nerve ring. Tail with 2 small spinelike projections.

Male (based on 20 mature specimens): Body 10.0 to $20.1 \mathrm{~mm}$ long by 80 to 141 wide at junction of muscular and glandular portions of esophagus, increasing posteriorly to between 131 and 299 at greatest width, 47 to 106 times longer than wide. Buccal capsule 54 to 75 long by 49 to 64 wide, containing 1 to 3 bifurcating spiral bands in 8 specimens. Esophagus 774 to 1,159 long, 5 to $8 \%$ of body length; muscular portion 382 to 465 long by 49 to 75 wide at bulb, comprising 37 to $49 \%$ of entire esophagus; glandular portion 400 to 694 long by 46 to 87 wide. Nerve ring 209 to 276 from cephalic end, 23 to 41 in breadth. Excretory pore 345 to 522 from anterior end, 134 to 281 posterior to nerve ring. Testis slightly sinuous; anterior portion looping 470 to 1,400 from cephalic end in region of glandular esophagus. Spicules gradually tapering posteriorly, ending with truncated tips; left spicule 224 to 257 long; right spicule similar, 429 to 552 long; spicule ratio $1: 1.4$ to 2.1 , averaging $1: 1.8$. Gubernaculum absent. Caudal alae united ventrally 226 to 500 from posterior end, supported by 8 symmetrical elon- 

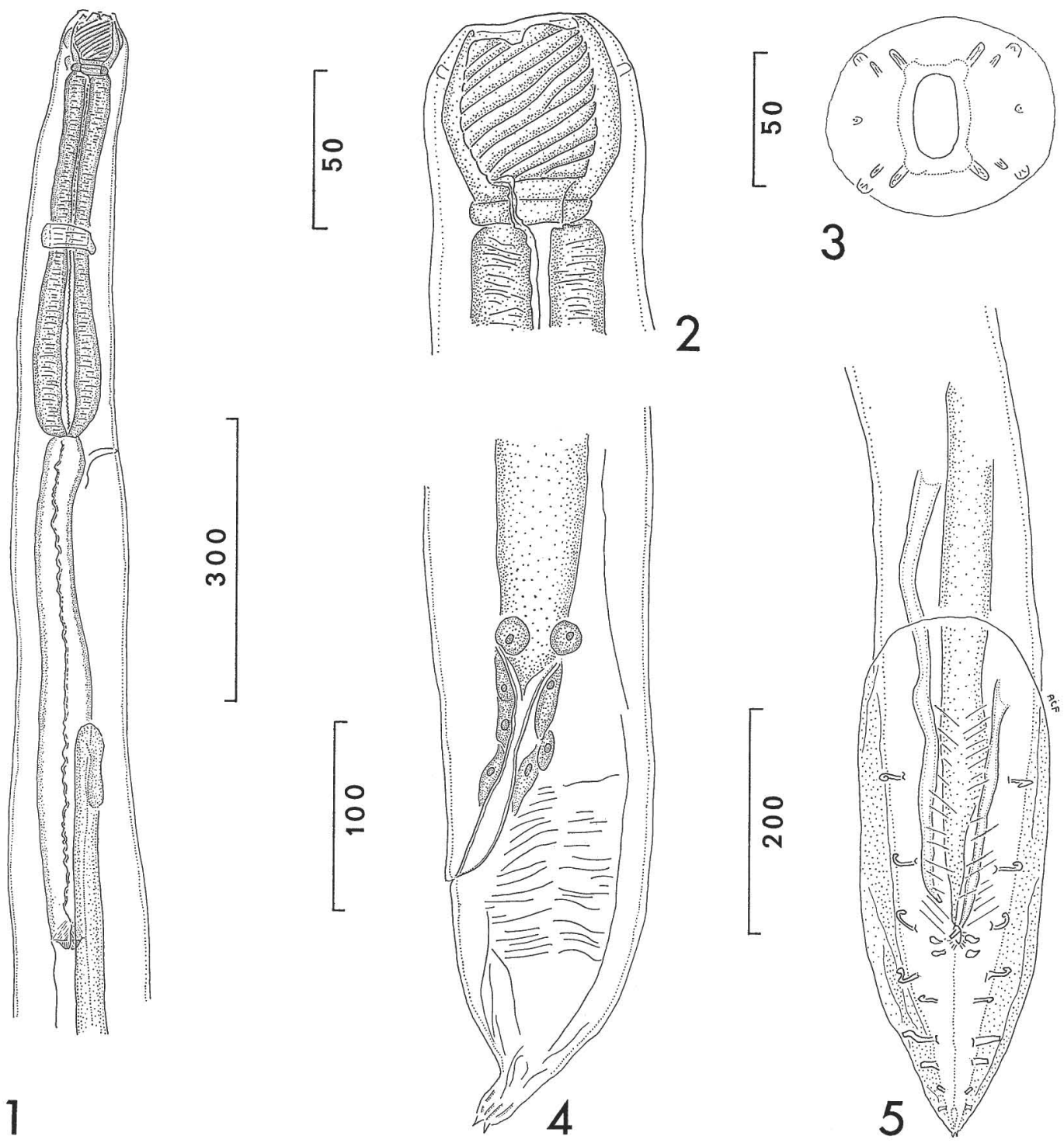

Figures 1-5. Spirocamallanus cricotus (scales in micrometers). 1. Anterior of male paratype, lateral view. 2. Cephalic region of male holotype, dorsal view. 3. En face of male. 4. Posterior end of female allotype, lateral view. 5. Posterior end of male paratype, ventral view.

gated pairs of papillae; precloacal pairs 3 of equal length; postcloacal pairs 5 with 1st and 3rd longer than others and 3rd and 4th wider than others; sessile adanal papillae-like structures 2 pairs, surrounding cloacal opening. Phasmids posterior to and about same size as posterior pair of papillae. Ventral transverse muscular bands prominent in anal region, extending from cloaca to near level of proximal end of left spicule. Tail flexed ventrad, 122 to 197 long; posterior end of worm with single coil.

Female (based on 20 mature specimens): Body
17.3 to $32.0 \mathrm{~mm}$ long by 128 to 241 wide at junction of muscular and glandular portions of esophagus, increasing posteriorly to between 260 and 476 at level of greatest width, 53 to 125 times longer than wide. Buccal capsule 72 to 83 long by 53 to 77 wide, containing 1 to 3 bifurcating spiral bands in 6 specimens. Esophagus 950 to 1,360 long, 4 to $6 \%$ of body length; muscular portion 420 to 593 long by 51 to 118 wide at bulb, 37 to $49 \%$ of entire esophagus; glandular portion 538 to 834 long by 53 to 100 wide. Nerve ring 192 to 328 from cephalic end, 26 to 58 in breadth. 
Excretory pore between 383 and 648 from anterior end, 173 to 320 posterior to nerve ring. Vulva situated 9.1 to $16.8 \mathrm{~mm}$ or 48 to $55 \%$ of body length from anterior end. Vagina vera straight, extending posteriorly from vulva, 309 to 467 long, 42 to 75 at widest point; vagina uterina approximately 2 to 4 times longer than vagina vera; uterus $\mathrm{J}$-shaped, saclike; anterior oviduct looping, forming swollen bulbous seminal receptacle; posterior ovidust indistinct; ovaries straight, directed posteriad; posterior ovary short, narrow, entering uterus at base of $\mathrm{J}$; anterior ovary cylindrical, usually extending beyond vulva, appoximately 20 to 60 times longer than posterior one. Tail 145 to 200 long including finger-like digit; digit with 2 associated spinelike projections 18 to $31 \%$ of tail length. Tail flexed slightly ventrad. Rectum 84 to 206 long, surrounded by 8 rectal glands in 2 columns of 4 along proximal $1 / 2$ to $3 / 4$ length of rectum. Larvae 444 to 493 long by 22 to 24 wide.

Type host: Micropogonias undulatus (Linnaeus), Atlantic croaker-Sciaenidae.

Other hosts: [Batrachoididae]: Opsanus beta (Goode and Bean), Gulf toadfish; [Bothidae]: Paralichthys lethostigma Jordan and Gilbert, southern flounder; [Cynoglossidae]: Symphurus plagiusa (Linnaeus), blackcheek tonguefish; [Cyprinodontidae]: Fundulus grandis Baird and Girard, Gulf killifish; [Eleotridae]: Eleotris pisonis (Gmelin), spinycheek sleeper; [Ophidiidae]: Ophidion welshi (Nichols and Breder), crested cusk-eel; [Polynemidae]: Polydactylus octonemus (Girard), Atlantic threadfin; [Sciaenidae]: Bairdiella chrysura (Lacépède), silver perch, Larimus fasciatus Holbrook, banded drum, Leiostomus xanthurus Lacépède, spot, Menticirrhus americanus (Linnaeus), southern kingfish; [Soleidae]: Trinectes maculatus (Bloch and Schneider), hogchoker.

Sites: Intestine, rarely in rectum and pyloric cecum.

Localities: Mississippi Sound and adjacent water.

Specimens deposited: Holotype male USNM Helm: Coll. No. 74560; allotype USNM Helm. Coll. No. 74561; paratypes (male and female) USNM Helm. Coll. No. 74562 and Colecaó Helminthologica do Instituto Oswaldo Cruz No. 31600.

Etymology: The Greek "cricotos" meaning "ringed" refers to the ledge located anterior to the basal ring of the buccal capsule.

\section{DISCUSSION}

Specimens of S. cricotus from the hosts listed above agree in all aspects with those described from Micropogonias undulatus. We assume the worm referred to as S. pereirai in Micropogon undulatus (= Micropogonias u.) from Louisiana by Sogandares-Bernal (1955) and from Texas by Joy (1971) are the same as ours. No type specimens of $S$. pereirai had been deposited in the United States National Museum
(Beltsville) (Lichtenfels, pers. comm.) as indicated by Annereaux (1946). Even though unsuccessful in contacting Annereaux, we examined specimens from Atherinopsis affinis (Ayres), Gillichthys mirabilis Cooper, and Fundulus parvipinnis Girard off Galeta, California, and found them different from ours. They agreed with the original description of S. pereirai by Annereaux (1946) from Atherinopsis californiensis Girard and additional data supplied by Noble and King (1960) from G. mirabilis. Additionally, the basal ring of the buccal capsule usually bears two small rounded processes anteriorly, the females have four rectal glands arranged in two columns of two along the rectum, and we consider what was described as the sixth pair of postcloacal papillae to represent phasmids. The phasmids open to the surface by a narrow pore.

Spirocamallanus cricotus is most similar to S. pereirai and S. macaensis in regard to the combination of length and width of body, size of buccal capsule and esophagus, number of spiral bands, arrangement of postcloacal papillae, a spicule ratio between $1: 1$ to 3.3 , and marine habitat. In S. pereirai, however, a ledge exists anterior to the basal ring of the buccal capsule, males have blunt rather than pointed spicules and ventral transverse muscular fibers extending anteriorly to the level of the left spicule rather than beyond the alae, and females have eight rather than four rectal glands. Slight differences also occur in spicule ratios and average spicule lengths between the two species. Spirocamallanus macaensis infects Menticirrhus americanus as does S. cricotus, but is known from near Rio de Janeiro, Brazil only (Vicente and Santo, 1972). It differs from S. cricotus by having dissimilar spicules with tapering pointed ends, a distinctly hooked right spicule, four pairs of postcloacal papillae, and cervical papillae (deirids). Spicule lengths and ratios also differ slightly between the two species. Male paratypes $30645 \mathrm{E}$ and D revealed a narrow secondary ledge on the buccal capsule's basal ring and a pair of phasmids near the end of the tail.

\section{Spirocamallanus halitrophus sp. $\mathbf{n}$.} (Figs. 6-10)

Description (based on specimens from Syacium papillosum ): Body with region of greatest width at midlevel or slightly anterior. Lips lacking, ce- 

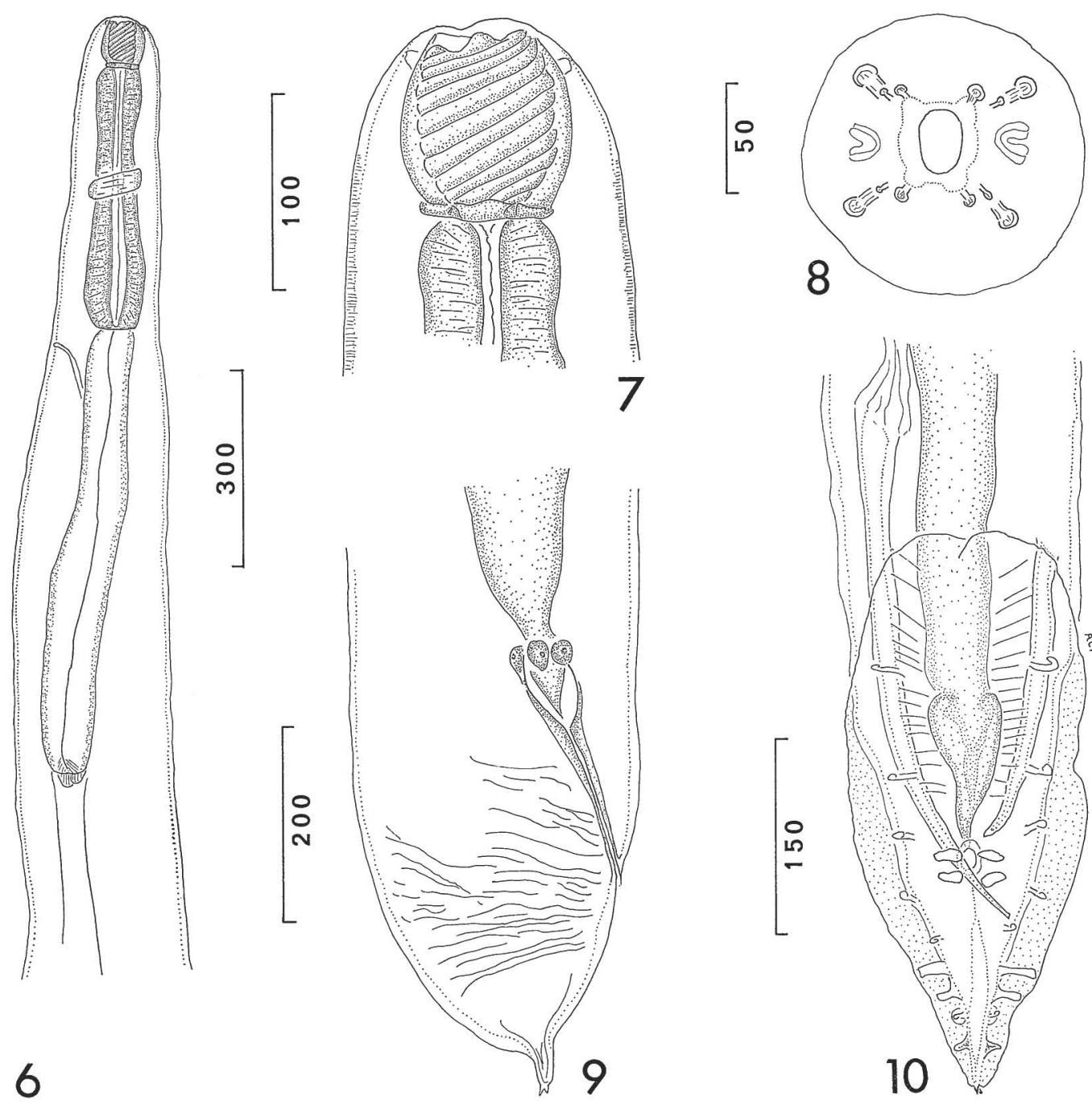

Figures 6-10. Spirocamallanus halitrophus (scales in micrometers). 6. Anterior of male paratype, lateral view. 7. Cephalic region of female paratype, ventral view. 8. En face of female. 9. Posterior end of female allotype, lateral view. 10. Posterior end of male paratype, ventral view; note phasmids dorsal to last pair of papillae.

phalic papillae elongated, in 3 concentric rings of 4 oriented $45^{\circ}$ from dorsal-ventral axis; amphids lateral. Mouth dorsoventrally elongated. Cuticle with fine transverse striations at anterior and posterior extremities, increasing to 2 to $3 \mu \mathrm{m}$ apart on remainder of body; longitudinal ridges wavy over much of the body. Deirids absent. Buccal capsule with 10 to 14 (avg 12.0) spiral bands counted diagonally. Esophagus with anterior muscular portion moderately club-shaped and posterior glandular portion elongated, ending in paired bilobed valves. Nerve ring slightly anterior to midpoint of muscular esophagus. Excretory pore posterior to nerve ring. Tail with 2 small spinelike projections.
Male (based on 16 mature specimens): Body 13.3 to $26.9 \mathrm{~mm}$ long by 161 to 212 wide at junction of muscular and glandular portions of esophagus, increasing posteriorly to between 247 and 379 at level of greatest width, 47 to 97 times longer than wide. Buccal capsule 86 to 98 long by 63 to 81 wide, containing 1 bifurcating spiral band in 1 specimen. Esophagus 959 to 1,359 long, 4 to $8 \%$ of body length; muscular portion 390 to 465 long by 80 to 119 wide at bulb, comprising 30 to $42 \%$ of entire esophagus; glandular portion 517 to 928 long by 69 to 155 wide. Nerve ring 247 to 316 from cephalic end, 32 to 38 in breadth. Excretory pore 431 to 603 from anterior end, 143 to 414 posterior to nerve ring. Testis slightly sinuous, 2 
to $5 \mathrm{~mm}$ from cephalic end in region of upper intestine. Spicules dissimilar; left spicule bluntly rounded distally, 183 to 324 long; right spicule truncated distally, 257 to 459 long; spicule ratio $1: 1.3$ to 1.8 , averaging $1: 1.5$. Gubernaculum absent. Caudal alae united ventrally 425 to 610 from posterior end, supported by 9 symmetrical, elongated pairs of papillae; precloacal pairs 3 , of equal length; postcloacal pairs 6 , with 3 rd and 4 th longer and wider than others, with 5th surrounded by oval pit-like recessions in alae; sessile adanal papilla-like structures 2 pairs surrounding cloacal opening. Phasmids located directly dorsal to last pair of papillae. Ventral transverse muscular bands prominent in anal region extending from slightly anterior to cloaca to beginning of alae. Tail flexed ventrad, 160 to 189 long; posterior end of worm with 1 to 2 coils.

Female (based on 15 mature specimens): Body 22.5 to $44.5 \mathrm{~mm}$ long by 220 to 325 wide at junction of muscular and glandular portions of esophagus, increasing posteriorly to between 522 to 754 at level of greatest width, 44 to 60 times longer than wide. Buccal capsule 96 to 121 long by 84 to 96 wide, lacking bifurcating spiral bands. Esophagus 1,147 to 1,537 long, 3 to $5 \%$ of body length; muscular portion 454 to 609 long by 92 to 132 wide at bulb, 37 to $42 \%$ of entire esophagus; glandular portion 696 to 963 long by 98 to 161 wide. Nerve ring 293 to 348 from cephalic end, 243 to 429 posterior to nerve ring. Vulva situated 11.8 to $22.2 \mathrm{~mm}$ or 47 to $54 \%$ of body length from anterior end. Vagina vera straight, extending posteriorly from vulva, 316 to 418 long, 69 to 109 at widest point; vagina uterina approximately 2 to 5 times longer than vagina vera; uterus J-shaped, saclike; oviducts usually extensively coiled; anterior oviduct 9 to 14 times longer than posterior one, forming sausage-shaped seminal receptacle 477 to 639 long by 81 to 135 wide; posterior oviduct entering uterus at base of $\mathrm{J}$, forming indistinct seminal receptacle. Ovaries usually straight, directed posteriad; posterior ovary short, narrow; anterior ovary elongate, cylindrical, beginning posterior to vulva, approximately 11 to 15 times longer than posterior ovary. Tail 191 to 255 long including finger-like digit; digit with 2 associated spinelike projections 19 to $29 \%$ of tail length. Rectum 189 to 276 long, surrounded by 4 rectal glands encircling anterior portion of rectum. Larvae 327 to 448 long by 12 to 24 wide.

Type host: Syacium papillosum (Linnaeus), dusky flounder-Bothidae.

Other hosts: Syacium gunteri Ginsburg, shoal flounder; [Ophidiidae]: Lepophidium brevibarbe (Cuvier), blackedge cusk-eel.

Localities: In water between 27 and $60 \mathrm{~m}$ deep, off Monroe County, Florida (type-locality), at Crocker Reef, Alligator Reef, Smith Shoal, and Islanada, and off the northwestern coast of Florida at $29^{\circ} 21^{\prime} \mathrm{N}, 84^{\circ} 49^{\prime} \mathrm{W}$; $5 \mathrm{~km}$ south of Horn Island Pass, Mississippi; off the coast of Alabama between $29^{\circ} 08^{\prime}$ to $29^{\circ} 55^{\prime} \mathrm{N}$ and $88^{\circ} 25^{\prime}$ to $88^{\circ} 45^{\prime} \mathrm{W}$; and the southern Gulf of Mexico in the Bay of Campeche, Mexico, at $21^{\circ} 15^{\prime} \mathrm{N}, 92^{\circ} 16^{\prime} \mathrm{W}$.

Specimens deposited: Holotype male USNM Helm. Coll. No. 74563; allotype USNM Helm. Coll. No. 74564; paratypes (male and female) USNM Helm. Coll. No. 74565 and Colecaó Helmintologica do Instituto Oswaldo Cruz No. 31601.

Etymology: The Greek "halitrophos" means "sea-dwelling" referring to the worm's presence in nonestuarine hosts.

\section{DISCUSSION}

Fraser (1971) referred to our specimens of Procamallanus sp. and noted that they infected more than half the examined Syacium papillosum and S. gunteri. They agree in all aspects with those from Lepophidium brevibarbe also obtained from offshore water. From the standpoint of length and width of body, length of esophagus, number of spiral bands, arrangement of postcloacal papillae, spicule ratio between $1: 1$ to 3.3 , and marine habitat, the most closely related species are $S$. cricotus, $S$. pereirai, and S. macaensis. Spirocamallanus halitrophus differs from the generally thinner $S$. cricotus by lacking a ledge anterior to the basal ring in the buccal capsule and having a larger buccal capsule, six rather than five postcloacal papillae arranged differently, the anteriormost tip of the testis not reaching so far anteriorly, and four rather than eight rectal glands in the female. It differs from S. macaensis by possessing six rather than four postcloacal papillae, a truncated right spicule instead of a distinctly hooked and pointed one, a spicule ratio of $1: 1.3$ to 1.8 instead of $1: 2.3$ to 2.4 , and by lacking cervical papillae. Spirocamallanus pereirai has five postcloacal papillae, a spicule ratio of $1: 1.9$ to 2.3 , and similar spicules in the male and two columns of two rectal glands along the rectum in the female.

\section{ACKNOWLEDGMENTS}

We are grateful to Dr. Fred Hochberg (Santa Barbara Museum of Natural History) for specimens of $\mathrm{S}$. pereirai from California, Mr. Martin F. Gomon (University of Miami) for the loan of specimens of Syacium papillosum, Dr. T. H. Fraser (Port Charlotte, Florida) for specimens from $S$. papillosum and S. gunteri, Mr. C. E. Dawson (Gulf Coast Research Laboratory) for the loan of specimens of Lepophidium brevibarbe, Dr. Ralph Lichtenfels (U.S. Department of Agriculture) and Mrs. 
Mary Lou Pritchard (University of Nebraska) for searching for types of S. pereirai, Dr. J. Julio Vicente (Instituto Oswaldo Cruz) for the loan of paratypes of S. macaensis, and Ronnie Palmer and Roswitha Buxton (GCRL) for technical assistance.

\section{LITERATURE CITED}

ALr, S. M. 1960. On two new species of Procamallanus Baylis, 1923 from India with a key to the species. J Helminthol 34: 129-138.

ANNEREAUX, R. F. 1946. A new nematode, Procamallanus pereirai with a key to the genus. Trans Am Microsc Soc 65: 299-303.

Bashirullat, A. K. M. 1973. Two new species of Spirocamallanus Olsen, 1952. Am Midl Nat 90: 221-224.

Fraser, T. H. 1971. Notes on the biology and systematics of the flatfish genus Syacium (Bothidae) in the straits of Florida. Bull Mar Sci 21: 491-509.

Joy, J. E. 1971. Spirocamallanus pereirai (Nematoda: Camallanidae) from the croaker, Micropogon undulatus, in Texas. J Parasitol 57: 390.
1974. Incidence and intensity of Spirocamallanus pereirai (Nematode: Camallanidae) infections in the croaker, Micropogon undulatus (Linnaeus) and spot, Leiostomus xanthurus Lacépède, from Texas. Contrib Mar Sci 18: 1-6.

Noble, E. R., ANd R. E. King. 1960. The ecology of the fish Gillichthys mirabilis and one of its nematode parasites. J Parasitol 46: 679-685.

Sogandares-Bernal, F. 1955. Some helminth parasites of fresh and brackish water fishes from Louisiana and Panama. J Parasitol 41: $587-594$.

Vicente, J. J., ANd E. Santo. 1972. Sobre um novo nematódeo camalanídeo parasito de peixe marinho (Nematoda, Camallanoidea). Atas Soc Biol Rio de Janeiro 15: 145-147.

Winter, H. A. 1953. Presencia de Spirocamallanus spiralis (Baylis, 1923) Olsen, 1952 (Nematoda) en peces marinos de aquas mexicanas. Ciencia Mexico City 13: 137-140.

Yamaguti, S. 1961. Systema Helminthum Vol. III. Part I. Interscience Publishers, New York. $1261 \mathrm{p}$

YEH, L. S. 1960. On a reconstruction of the genus Camallanus Railliet and Henry, 1915. J Helminthol 34: 117-124. 